\title{
Molecular and Microscopic Insights into the Formation of Soil Organic Matter in a Red Pine Rhizosphere
}

\author{
Alice C. Dohnalkova ${ }^{1, *}$ (D), Malak M. Tfaily ${ }^{1}$, A. Peyton Smith ${ }^{2}$ (D), Rosalie K. Chu ${ }^{1}$, \\ Alex R. Crump ${ }^{3}$ (D), Colin J. Brislawn ${ }^{2}$, Tamas Varga ${ }^{1}$ (iD), Zhenqing Shi ${ }^{4}$, Linda S. Thomashow ${ }^{5}$, \\ James B. Harsh ${ }^{6}$ and C. Kent Keller ${ }^{7}$ \\ 1 Environmental Molecular Sciences Laboratory, Pacific Northwest National Laboratory, Richland, WA 99352, \\ USA; malak.tfaily@pnnl.gov (M.M.T.); Rosalie.Chu@pnnl.gov (R.K.C.); Tamas.Varga@pnnl.gov (T.V.) \\ 2 Biological Sciences Division, Pacific Northwest National Laboratory, Richland, WA 99352, USA; \\ peyton.smith@pnnl.gov (A.P.S.); colin.brislawn@pnnl.gov (C.J.B.) \\ 3 Department of Soil and Water Systems, University of Idaho, Moscow, ID 83844, USA; acrump@uidaho.edu \\ 4 School of Environment and Energy, South China University of Technology, Guangdong 510006, China; \\ zqshi@scut.edu.cn \\ 5 USDA-ARS, Wheat Health, Genetics and Quality Research Unit, Washington State University, Pullman, \\ WA 99164,USA; thomashow@wsu.edu \\ 6 Department of Crop \& Soil Sciences, Washington State University, Pullman, WA 99164, USA; harsh@wsu.edu \\ 7 School of the Environment, Washington State University, Pullman, WA 99164, USA; ckkeller@wsu.edu \\ * Correspondence: alice.dohnalkova@pnnl.gov; Tel.: +1-509-371-6515
}

Received: 15 June 2017; Accepted: 24 August 2017; Published: 26 August 2017

\begin{abstract}
Microbially-derived carbon inputs to soils play an important role in forming soil organic matter (SOM), but detailed knowledge of basic mechanisms of carbon (C) cycling, such as stabilization of organic $\mathrm{C}$ compounds originating from rhizodeposition, is scarce. This study aimed to investigate the stability of rhizosphere-produced carbon components in a model laboratory mesocosm of Pinus resinosa grown in a designed mineral soil mix with limited nutrients. We utilized a suite of advanced imaging and molecular techniques to obtain a molecular-level identification of newly-formed SOM compounds, and considered implications regarding their degree of long-term persistence. The microbes in this controlled, nutrient-limited system, without pre-existing organic matter, produced extracellular polymeric substances that formed associations with nutrient-bearing minerals and contributed to the microbial mineral weathering process. Electron microscopy revealed unique ultrastructural residual signatures of biogenic $C$ compounds, and the increased presence of an amorphous organic phase associated with the mineral phase was evidenced by $\mathrm{X}$-ray diffraction. These findings provide insight into the formation of SOM products in ecosystems, and show that the plant- and microbially-derived material associated with mineral matrices may be important components in current soil carbon models.
\end{abstract}

Keywords: rhizosphere; soil organic matter; soil microbiome; $16 \mathrm{~S}$ sequencing; mineral weathering; Fourier-transform ion cyclotron resonance mass spectrometry; electron microscopy; mineral-organic associations; carbon cycle

\section{Introduction}

Soils play a critical role in global carbon cycling, having a dynamic carbon reservoir in the form of soil organic matter (SOM) that is estimated to be four times larger than the amount stored in the atmosphere [1,2]. In 2010, a new conceptual framework for a microbial carbon pump was proposed for the microbial production of recalcitrant non-living organic matter and the storage of fixed $\mathrm{C}$ in 
oceans [3]. The related idea of a C pump that operates in terrestrial systems was subsequently proposed in 2011 [4,5]. Detailed investigations of a microbial carbon pump in soils presents an area of several knowledge gaps, and a benchmark for upcoming research. Recently, new research on microbial carbon stabilization in soils has emerged, focusing on SOM molecular structure characterization, recalcitrance, and persistence [6-8], as well as studies showing the importance of microbially-derived C for stabilized SOM [9] and a conceptual framework for SOM stabilization $[9,10]$. Understanding the dynamics of C pools in soil systems is critical for controlling atmospheric carbon dioxide levels and maintaining soil health and agricultural productivity. Microbial contributions to long-lived soil C pools has often have been regarded as low to negligible, partly because the carbon in living microbial biomass accounts for less than $4 \%$ of soil organic carbon [11]. However, microorganisms add carbon to soil through rapid and persistent cell division, community growth, exudation of biogenic products, and cell death [12]. More recently, there has been a greater recognition that microbial necromass, i.e., dead microbial biomass, may contribute to SOM pools that have longer turnover times [13-15]. Microbially-derived C inputs to soils are now increasingly recognized as playing a far greater role in sequestration of SOM than previously believed [16]. A new concept has been introduced, contrasting the traditional view of recalcitrant humic substances against the emergent paradigm with a "continuum of progressively decomposing organic compounds" [17]. The challenges of characterizing the SOM pool need to be addressed through the development of high spatial, chemical, and molecular resolution techniques. A comprehensive review by Oburger and Schmidt [18] discusses approaches for research on C input in soils. Mikutta et al. [19] and Pett-Ridge and Firestone [20] present stable isotope-enabled capabilities for tracing dynamic processes of organic molecules from roots and microorganisms in SOM. Employing multimodal analytical approaches that combine physical, chemical, and biological techniques may bring us closer to addressing these research questions.

The rhizosphere, the zone immediately adjacent to plant roots, represents a hotspot of carbon exudation, turnover, respiration, transformation, and accumulation [21]. Depending on the plant, 5 to $21 \%$ of atmospheric $C$ that is photosynthetically fixed is transformed into root exudates [22,23]. The importance of roots for the formation of SOM is discussed in Rasse et al. [24], with the root contribution to soil C pools as a key factor of SOM stabilization. These rhizospheric $\mathrm{C}$ compounds consist of easily degradable sugars and organic acids, as well as more recalcitrant materials including lignified cellulose and hemicellulose from sloughed-off root cells [25]. These plant-specific growth substrates readily recruit rhizospheric soil microorganisms, which subsequently metabolize and decompose these and other rhizodeposits high in labile C. Additionally, microbially-secreted extracellular polymeric substances (EPS) play a dynamic role in numerous soil processes, including soil $C$ stabilization on mineral surfaces and mineral weathering [26,27]. These rhizospheric compounds released by plants and microbes contribute a substantial amount of organic $C$ to soils. Depending on the susceptibility of these rhizospheric compounds to degradation and mineralization, they may become stabilized, and a part of the newly formed refractory SOM of plant and microbial origin (Figure 1). 


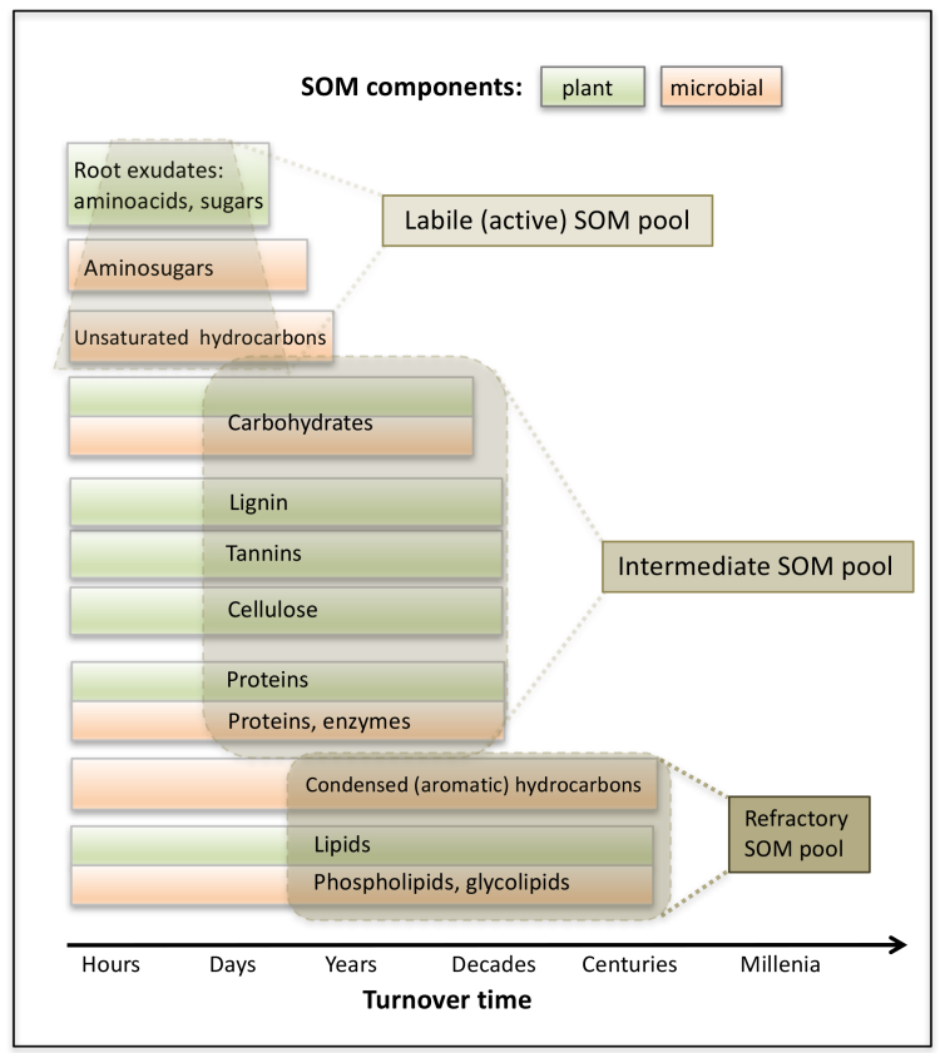

Figure 1. Classification and residence time of plant and microbial residue, based on inherent chemical recalcitrance of various SOM compounds. Adapted from Lorenz [28], Kuzyakov [21], and von Lützow [29].

The objective of this research was to gain insight into the role soil microorganisms play in C stabilization. In addition, the research aimed to develop a molecular understanding of newly formed SOM macromolecules produced by root exudates and microbes in the rhizosphere of red pine seedlings, in a controlled conditions experiment without any previous humic substances in the designed mineral matrix. The system was maintained under base cation-limited conditions in order to drive utilization of minerals in the substrate as cations source. Laboratory and field experiments have shown that plants and their microbial affiliates can extract and utilize base cations such as $\mathrm{K}$ and $\mathrm{Ca}$ from soil minerals when exposed to soil solutes lacking these cations resulting in increased mineral weathering [30-33]. We anticipated that (a) microbes would contribute to the new SOM pool by stabilizing root exudates and producing complex refractory $\mathrm{C}$ compounds. With our recent development of a solvent-based method for molecular SOM characterization by high resolution mass spectrometry [34], we also expected that (b) microbial residues will leave a stable signature of persistent $\mathrm{OM}$ on mineral surfaces that remain attached following a series of extractions with different polarity solvents. Furthermore, we hypothesized that (c) SOM composition would differ between rhizosphere soil and bulk soil. To achieve these objectives, we implemented a collective approach of imaging and molecular methods (Figure 2) allowing us to characterize the nature and extent of refractory microbial material in the SOM. We categorized the organic $C$ compounds based on elemental composition, biochemical classes, and lability and persistence. 


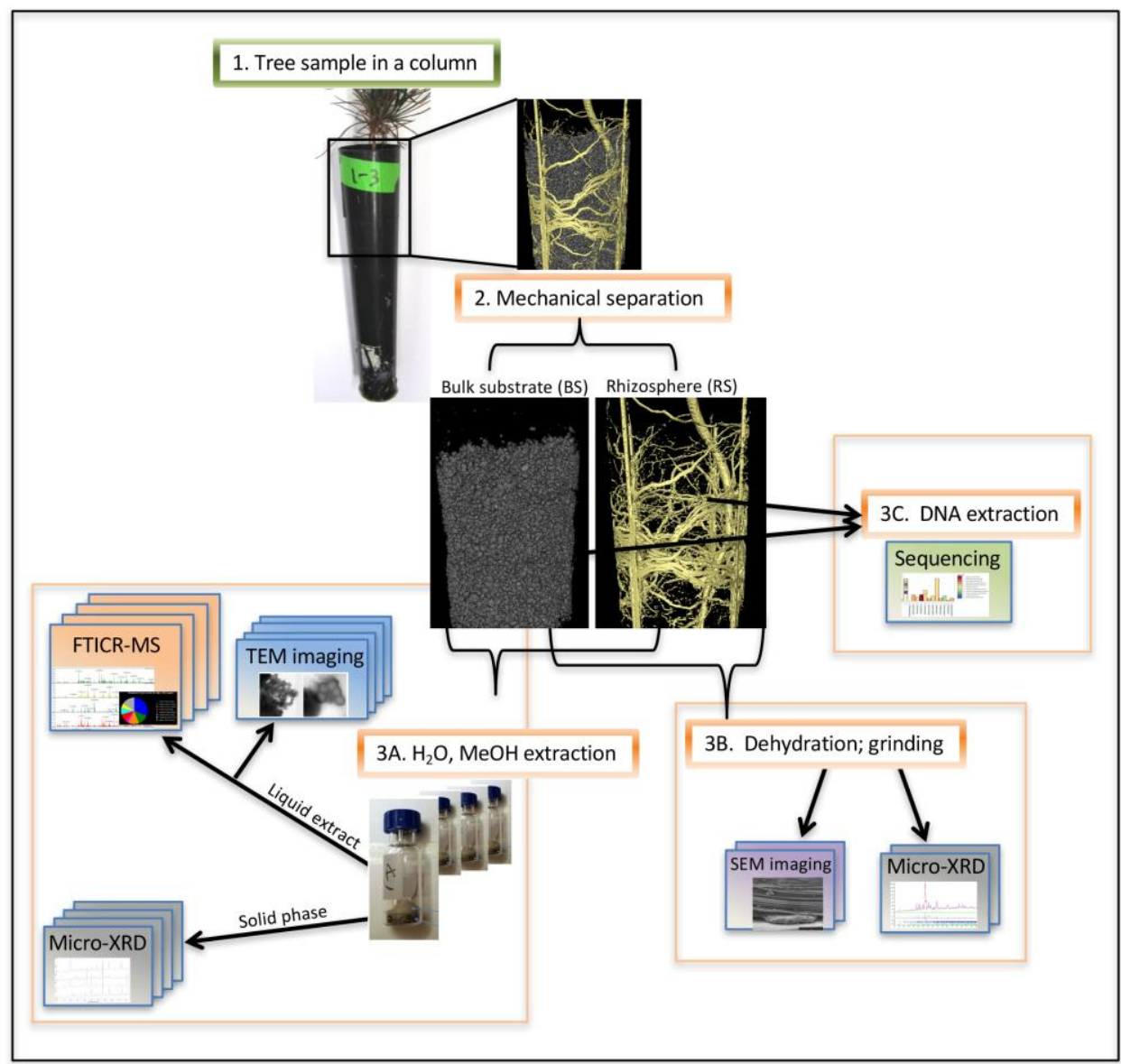

Figure 2. A schematic illustration of the experimental design.

\section{Materials and Methods}

\subsection{Experimental Approach}

Thirty six seedlings of red pine (Pinus resinosa), a pine species native to North America, were planted into $164 \mathrm{~mL}$ Ray Leach plastic cone-tainers ${ }^{\mathrm{TM}}$ (Steuwe and Sons, Tangent, OR, USA) that had been closed at the bottom with $60 \mu \mathrm{m}$ nylon mesh [32] and filled with $170 \mathrm{~g}$ of sterilized quartz sand amended with $1.5 \%$ biotite and $1 \%$ anorthite by weight (Figure 2,1 . Tree sample in a column). These minerals were the seedlings' sole source of Ca and K. See Shi et al. [32] for more details, and Supplementary Information for the sterile medium mineral constituency, growth conditions, and microbial inoculum. To establish a rhizosphere microbial community comparable to those occurring under pine forest conditions, an inoculum consisting of a microbial suspension was prepared by washing roots of young white pine trees collected about 20 miles North-East of Potlatch, ID (46.9 $9^{\circ}$, $116.9^{\circ} \mathrm{W}$ ). Time zero for the start of the column experiment was defined when $5 \mathrm{~mL}$ of inoculum was added to each mesocosm. The trees were provided with $20 \mathrm{~mL}$ of distilled water three times per week. After nine months, the columns were destructively assessed using the suite of analytical and imaging methods listed below (Figure 2, 2. Mechanical separation). Twelve biological replicates (trees) were used for the FTICR and ion microscopy, and 4 separate trees with a total of 30 technical replicates for microbial DNA extraction. The material for XRD was combined from the above samples after the respective analysis or treatment (extraction). Briefly, seedlings were harvested by gently rolling the cone-tainer to loosen the roots, and the seedlings and the soil core were placed on a clean surface. To isolate the rhizosphere from the bulk soil, the bulk substrate (BS) was first gently shaken off and collected, followed by more vigorous shaking to free the soil that remained loosely associated 
with the root. The material that remained closely adhered to the root was defined as the rhizospheric material (RS).

\subsection{Microbial DNA Extraction, Sequencing, and Data Analysis}

Microbial diversity and community composition were determined by $16 \mathrm{~S}$ rRNA amplicon sequencing and subsequent taxonomic analysis. Four biological replicates of red pine seedlings were sampled at 9 months after inoculation, each in two respective profiles: bulk substrate (BS) and rhizospheric material (RS) (Figure 2, 3C. DNA extraction). However, only data from the RS was used in this study due to a lack of amplifiable material extracted from the BS. Microbial DNA was extracted using a MoBio PowerSoil ${ }^{\circledR}$ DNA Isolation Kit (MoBio Laboratories, Inc., Carlsbad, CA, USA) following the manufacturer's instructions. Eluted DNA was quantified with a QuBit ${ }^{\circledR}$ 2.0 Fluorometer and QuBit ${ }^{\circledR}$ dsDNA HS (high sensitivity) Assay Kit (Invitrogen, Carlsbad, CA, USA). The quality of the DNA product was checked by PCR amplification of the V4 region (515f-806r) of the 16S rRNA gene by using the protocol developed by the Earth Microbiome Project (http://press.igsb.anl.gov/earthmicrobiome/emp-standard-protocols/16s/), with a Taq PCR Master Mix Kit (Qiagen, Hilden, GE, USA) and a DNA Engine Tetrad 2 Peltier thermocycler (Bio Rad, Hercules, CA, USA). PCR conditions and details pertaining to the primer set are described in Caporaso et al [35]. Eluted DNA was stored at $-20^{\circ} \mathrm{C}$ and subsamples $(20 \mu \mathrm{L})$ from each biological replicate were sent to Argonne National Laboratory (ANL) for sequencing on the Illumina HiSeq2000.

Reads were demultiplexed, joined, and quality filtered using ea-utils [36], then analyzed with QIIME [37]. VSEARCH [38], an optimal, open-source implementation of USEARCH, was used to dereplicate, sort by abundance, remove single reads, and cluster at $97 \%$ identity. The UCHIME algorithm as implemented in VSEARCH was used to check these clusters for chimeras and construct an abundance table by mapping labeled reads to chimera-checked clusters [39]. Taxonomy was assigned to the centroid of each operational taxonomic unit (OTU) by finding the last common ancestor of the top three hits to the Greengenes database [40]. The centroids were aligned to the database and a phylogenetic tree was constructed using FastTree [41].

\subsection{Fourier Transform Ion Cyclotron Resonance Mass Spectrometry (FTICR-MS)}

Biological replicates of red pine seedlings were sampled at 9 months after inoculation.

After the mechanical separation of the material from the columns (Figure 2, 2. Mechanical separation), samples of bulk substrate (BS) and rhizospheric material (RS) were extracted in either water (Optima ${ }^{\circledR}$ LC /MS grade, Fisher Scientific, Suwanee, GA, USA) or 100\% methanol (Optima ${ }^{\circledR}$ HPLC grade, Fisher Scientific, Suwanee, GA, USA) according to Tfaily et al. [34] as follows: $0.5 \mathrm{~g}$ of BS or RS were weighed and divided evenly for water and methanol extraction, then mixed and shaken for 5 minutes. For RS, root samples were dipped in the solvent, manually stirred and gently shaken for 5 minutes, to minimize the portions of cut roots to be extracted in water or methanol. (Figure 2, 3A. $\mathrm{H}_{2} \mathrm{O}, \mathrm{MeOH}$ extraction). Water was the solvent of choice to extract labile compounds such as sugars and amino acids, in addition to polar lignin-like and aromatic compounds. Methanol was used as a complementary solvent to water and was used to extract compounds with low O:C elemental ratios in addition to polar lipid-like compounds. After the extraction, the material was spun down, and solvents with extracted material were collected for FTICR-MS analysis and TEM imaging. To obtain high-resolution FTICR mass spectra of the organic matter in the extracts, the analysis was performed using a 12 Tesla 12T-FTICR-MS (Bruker SolariX, Billerica, MA, USA) outfitted with standard electrospray ionization (ESI) interface. The spectra were collected in negative ion mode. Water-extracted samples were diluted 1:2 with methanol and methanol extracted samples were run directly and infused using a $250 \mu \mathrm{L}$ Hamilton syringe at a flow rate of $3 \mu \mathrm{L} / \mathrm{min}$. The coated glass capillary temperature was set to $180{ }^{\circ} \mathrm{C}$ and the electrospray voltage set to $+4.4 \mathrm{kV}$. The ESI signal was allowed to stabilize for $5 \mathrm{~min}$ and data were then collected from 100 to $1300 \mathrm{~m} / \mathrm{z}$, resolution was $4.5 \times 10^{5}$ at $451 \mathrm{Da}$, ion accumulation time was $0.1 \mathrm{~s}$ for 96 scan averages co-added, time of flight was 
set to $0.65 \mathrm{~ms}$, and Q1 was set to $100 \mathrm{~m} / \mathrm{z}$. The syringe was then flushed with $50 / 50$ methanol/water $(v / v)$ to prepare for the next sample. Spectra were calibrated by two internal series of DOM homologous series separated by $14 \mathrm{Da}\left(-\mathrm{CH}_{2}\right.$ groups) and the mass accuracy was calculated to be $<1 \mathrm{ppm}$ for singly charged ions ranging across the mass spectra distribution. Molecular formula assignments were made using a modified version of the Compound Identification Algorithm (CIA) described by Kujawinski et al. [42] and updated as described subsequently [43]. Biochemical compound classes are reported as relative abundance values based on counts of $\mathrm{C}, \mathrm{H}$, and $\mathrm{O}$ for the following $\mathrm{H}: \mathrm{C}$ and $\mathrm{O}: \mathrm{C}$ ranges; lipids $(0<\mathrm{O}: \mathrm{C} \leq 0.3,1.7 \leq \mathrm{H}: \mathrm{C} \leq 2.4)$, unsaturated hydrocarbons $(0 \leq \mathrm{O}: \mathrm{C} \leq 0.125$, $0.8 \leq \mathrm{H}: \mathrm{C}<2.5)$, proteins $(0.3<\mathrm{O}: \mathrm{C} \leq 0.55,1.5 \leq \mathrm{H}: \mathrm{C} \leq 1.9)$, amino sugars $(0.55<\mathrm{O}: \mathrm{C} \leq 0.7$, $1.5 \leq \mathrm{H}: \mathrm{C} \leq 1.9)$, cellulose $(0.7<\mathrm{O}: \mathrm{C} \leq 1.1,1.5 \leq \mathrm{H}: \mathrm{C}<2.3)$, carbohydrates $(0.7<\mathrm{O}: \mathrm{C} \leq 1.5$, $1.5 \leq \mathrm{H}: \mathrm{C} \leq 2.5)$, lignin $(0.3<\mathrm{O}: \mathrm{C} \leq 0.6,0.8 \leq \mathrm{H}: \mathrm{C}<1.5)$, tannins $(0.65<\mathrm{O}: \mathrm{C} \leq 1.1,0.7 \leq \mathrm{H}: \mathrm{C}<1.4)$, and condensed aromatics (0.5 $\leq \mathrm{O}: \mathrm{C} \leq 0.9,0.2 \leq \mathrm{H}: \mathrm{C}<0.8)$ ([34], modified from Kim et al. [44]). Spectra from water-extracted samples were selective for carbohydrates with high O:C ratios, whereas spectra from methanol-extracted samples were selective for compounds with low $\mathrm{O}: \mathrm{C}$ rations $(\mathrm{O}: \mathrm{C}<0.5)$ [34]. The van Krevelen diagram is constructed using the elemental oxygen-to-carbon ratio $(\mathrm{O} / \mathrm{C}$ ratio) on the $\mathrm{x}$-axis and hydrogen to carbon $(\mathrm{H} / \mathrm{C}$ ratio) on the $\mathrm{y}$-axis. Major biogeochemical classes of compounds (such as lignin-like compounds, lipid-like compounds etc.) have their own characteristic $\mathrm{H} / \mathrm{C}$ or $\mathrm{O} / \mathrm{C}$ ratios. As a result, each class of compounds plots in a specific location on the diagram [44].

\subsection{Transmission Electron Microscopy (TEM)}

A whole mount approach was applied for imaging the material extracted from rhizospheric soils using the same solvents that were utilized for the FTICR-MS analysis (Figure 2, TEM imaging). A 5- $\mu \mathrm{L}$ drop of water or methanol with extracted material was applied to a 100-mesh $\mathrm{Cu}$ grid covered with formvar support film sputtered with carbon (Electron Microscopy Sciences, Hatfield, PA, USA). The material was allowed to adhere to the grid for $1 \mathrm{~min}$ before the liquid was gently blotted with a filter paper, and the material was negatively stained with a 5-uL drop of Nano-W (Nanoprobes, Yaphank, NY, USA). After $30 \mathrm{~s}$, the excess liquid was removed by wicking and the sample was allowed to air dry. Samples were examined with a Tecnai T-12 TEM (FEI) operating at $120 \mathrm{kV}$ with a LaB6 filament. Images were collected digitally with a $2 \times 2 \mathrm{~K}$ UltraScan CCD (Gatan, Pleasanton, CA, USA). Representative images of at least 50 areas per sample were collected at 10,000 $\times$ magnification and analyzed to distinguish the representative material ultrastructure.

\subsection{Scanning Ion Microscopy-Helium Ion Microscopy (HeIM)}

Mineral material from the same samples as for the FTICR was air-dried, then mounted on carbon tape-covered aluminum SEM stubs (Ted Pella, Redding, CA, USA), and sputter-coated with carbon. The mineral particles were imaged with a high-resolution Orion Helium ion microscope (HeIM) (Zeiss, Peabody, MA, USA) at $30 \mathrm{kV}$ (Figure 2, 3B. Dehydration; SEM imaging).

\subsection{XRD, Micro-XRD}

Solid material from the same samples as for the FTICR and HeIM, (bulk substrate and rhizosphere, $0.5 \mathrm{~g}$ each), were homogenized into fine powder by dry grinding, and loaded into 0.5 -mm diameter quartz capillaries (Charles Supper Co., Natick, MA, USA) for micro-XRD measurements (Figure 2, 3A. $\mathrm{H}_{2} \mathrm{O}, \mathrm{MeOH}$ extraction, Solid phase, Micro-XRD; and 3B. Grinding, Micro-XRD). Data were collected using a Rigaku D/Max Rapid II instrument equipped with a 2D image plate detector (The Woodlands, TX, USA). X-rays were generated with a MicroMax 007HF generator fitted with a rotating $\mathrm{Cr}$ anode $($ Lambda $=2.2897 \AA)$, and focused on the specimen through a $300 \mu \mathrm{m}$ diameter collimator. 2DP, a Rigaku 2D Data Processing Software (Ver. 1.0, Rigaku, 2007) was used to integrate the diffraction rings captured by the detector. Regular powder diffraction data were collected on a Phillips X'Pert Multipurpose X-ray diffractometer equipped with a fixed $\mathrm{Cu}$ anode operating at $45 \mathrm{kV}$ and $40 \mathrm{~mA}$. Analysis of the diffraction data for phase matching was carried out using JADE 9.5 (Materials Data, Inc., 
Livermore, CA, USA) and the PDF4 + 2014 database from ICDD. For the determination of amorphous content, a known amount of high-crystallinity corundum internal standard (a-Al2O3, NIST Standard Reference Material 674a) was mixed into the samples, and the amorphous content of the samples was calculated using formula [45]:

Real amorphous fraction $(\mathrm{Wi})$

$$
W i=\left[\frac{1}{1-W s}\right] \cdot\left[1-\left(\frac{W s}{W s c}\right)\right]
$$

as implemented in the program TOPAS v4.2 (Bruker AXS GmbH, Karlsruhe, Germany), where Ws is the experimental weight fraction of internal standard (corundum), and Wsc is the calculated weight fraction of internal standard from the refinement.

\section{Results}

\subsection{Column Growth Experiment}

In nutrient-limited conditions, and in the absence of pre-existing humic soil components in the system, the experimental mesocosm sustained a diverse microbial community and produced a variety of organic compounds. The mineral matrix was initially sterile, thus all detected SOM was created by tree root exudates and microbial metabolism in situ. The plants exhibited stunted growth after 9 months of dependence on nutrients ( $\mathrm{Ca}$ and $\mathrm{K}$ ) released from minerals by the root system and its microbial affiliates. There was no leaf litter influence because the young trees did not undergo senescence.

\subsection{Microbial Community Composition}

Microbial community operational taxonomic units (OTUs) were solely observed in the rhizospheric material; the bulk substrate lacked an extracted signal that could be amplified. In the rhizospheric soil, the most common families of microorganisms accounted for $>95 \%$ of all observations (Figure 3A). These represented ten bacterial phyla, with Proteobacteria being the most abundant, comprising $73 \%$ of the community. The most common orders of Proteobacteria observed were Burkholderiales, Rhizobiales, Pseudomonacterdales, and Nitrosomonadales (Figure 3A). We also observed abundant Saprospirales, Sphingobacteriales (from phylum Bacteriodetes), Actinomycetales (from phylum Actinobacteria), and Solibacterales (from phylum Acidobacteria) in RS. These taxa were present in rhizospheric soil of all four sampled columns with no significant variations of microbial community composition across biological and technical replicates. Family relatedness is shown using an inferred phylogenetic tree (Figure 3B). This phylogenetic tree shows that in the rhizospheric soil, Actinobacteria were closely related to each other and differed from the majority of other Proteobacteria, which also tended to be grouped together. The Rhizobiales were also clustered together. Out of the OTUs identified as being in the order Rhizobiales, the most abundant families included Bradyrhizobiaceae (5.4\%), Phyllobacteriaceae (4.2\%), and Hyphomicrobiaceae (4.1\%) (Figure 4). 


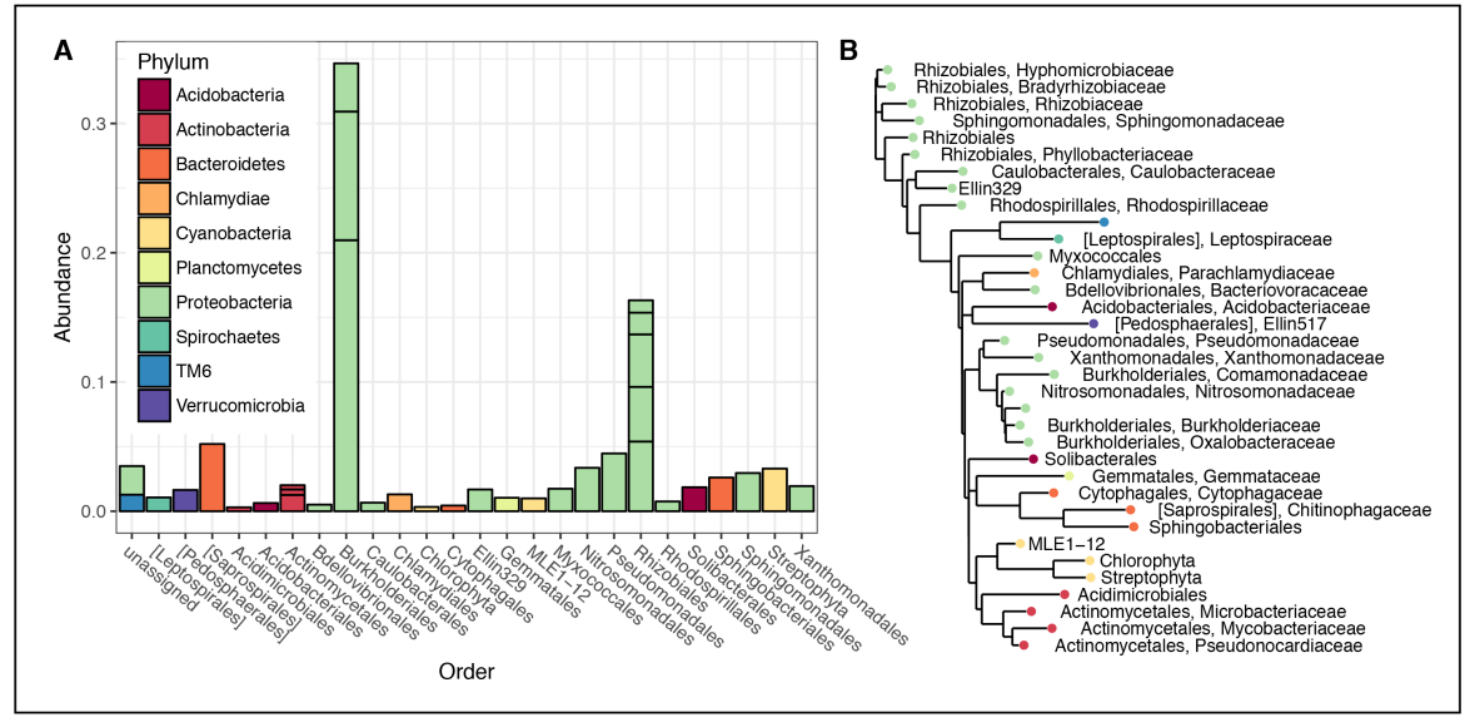

Figure 3. Rhizosphere soil microbial community composition identified by DNA sequencing. (A) A bar plot of the most abundant microbial families grouped by order. (B) A phylogenetic tree shows the relatedness of these most common microbial families.

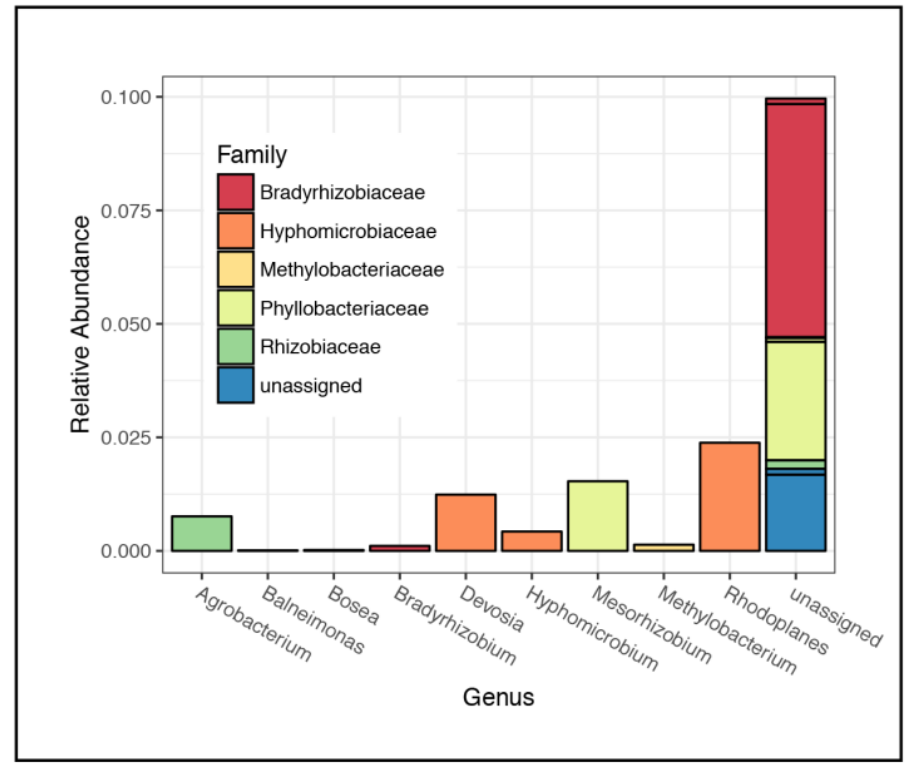

Figure 4. Relative abundance of operational taxonomic units from the order Rhizobiales separated by genus (x-axis) and family (colored legend).

\subsection{FTICR-MS}

We characterized the chemical complexity and composition of the newly formed carbon compounds. Figure 5 summarizes these data from one of the biological replicates in a van Krevelen diagram which is a plot of the elemental ratios of $\mathrm{O}: \mathrm{C}$ on the $\mathrm{x}$-axis and $\mathrm{H}: \mathrm{C}$ on the $\mathrm{y}$-axis. All column samples showed a substantial presence of biochemical compounds extracted by water and methanol (Figure 5), especially in the RS. Additionally, each solvent was selective for the type of compounds that it extracted. In the water-extracted samples, a decrease in the \% abundance of lignin-like, protein-like, and amino sugar-like compounds was observed in the BS (Figure 6) compared to RS. Lignin-like compounds are of plant origin compared to protein-like and amino sugar compounds that could be a mix of both plant and microbial origin (Figure 1). The bulk substrate sample was mainly enriched in 
aromatic compounds with little to no labile compounds. In the methanol-extracted samples, both the BS and RS appeared to be rich in lipid-like compounds that could be of plant and microbial origin, even though a higher abundance of these compounds was observed in RS samples.

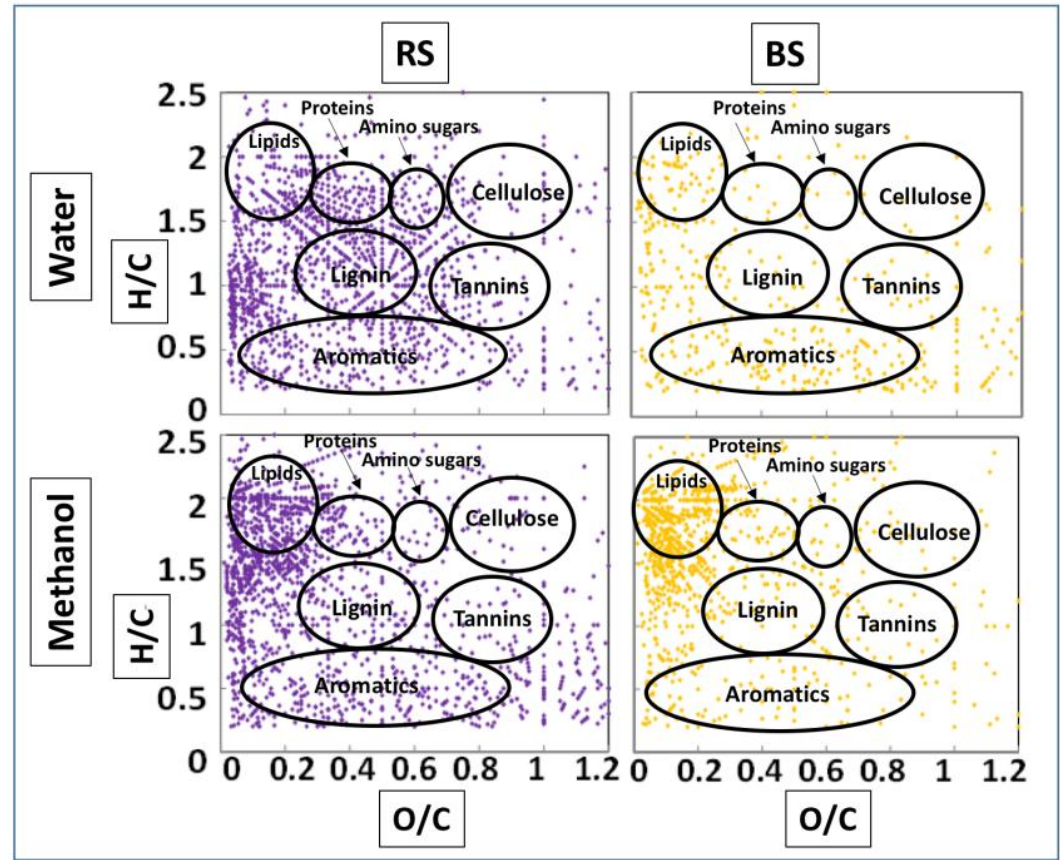

Figure 5. Van Krevelen diagrams of SOM compounds extracted by water and methanol, from rhizosphere (RS) and bulk substrate (BS).

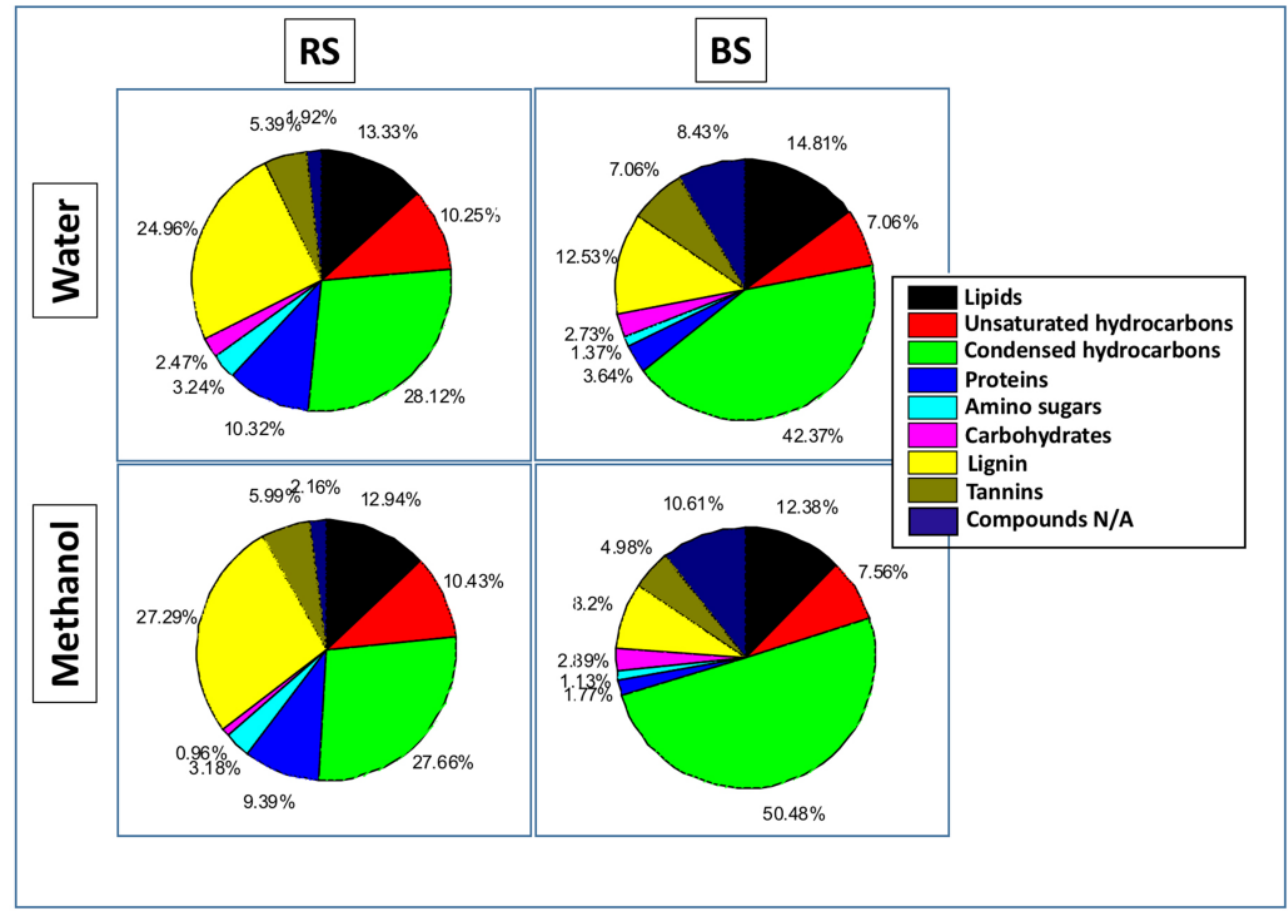

Figure 6. Relative abundance of different compound classes uniquely extracted by water and methanol, from rhizosphere (RS) and bulk substrate (BS). 


\subsection{TEM}

The high resolution TEM imaging revealed a clear difference in appearance in the water- and methanol-extracted material (Figure 7), consistent with FTICR-MS data. The material dissolved in water showed ultrastructure indicative of morphologically indistinct precipitation of components dissolved in water upon air dying. In contrast, the SOM material extracted into the methanol phase exhibited circular features of size ranging from $50 \mathrm{~nm}$ to $1 \mu \mathrm{m}$ suggestive of an emulsion of lipid-like compounds in methanol, consistent with FTICR-MS data (Van Krevelen diagrams in Figure 5).

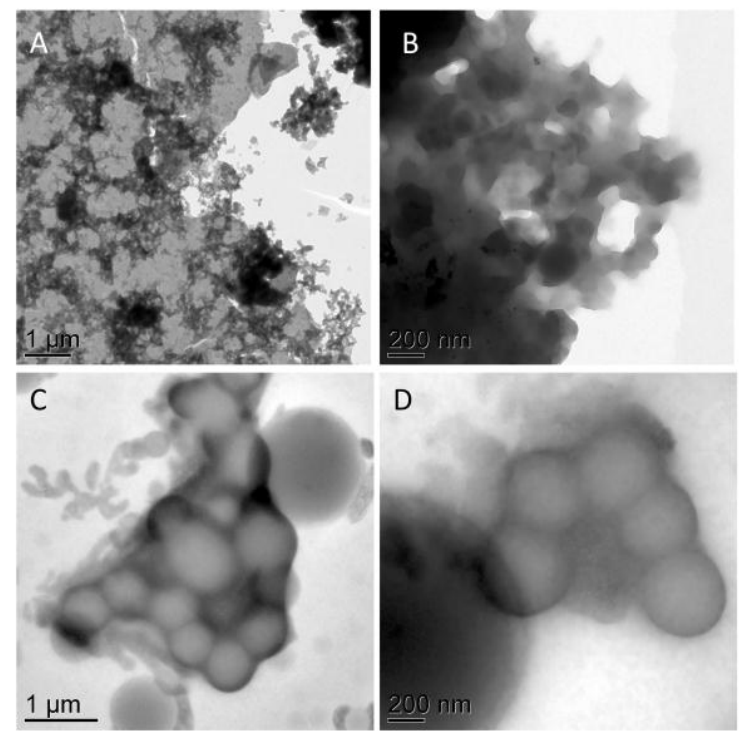

Figure 7. TEM images of water-soluble (A,B) and MeOH-soluble (C,D) extracted SOM content.

\subsection{HeIM}

Minerals from the rhizosphere showed adhesion of microbial EPS onto surfaces, as well as intercalation and deposition of OM into the interlayer space of biotite (Figure 8).

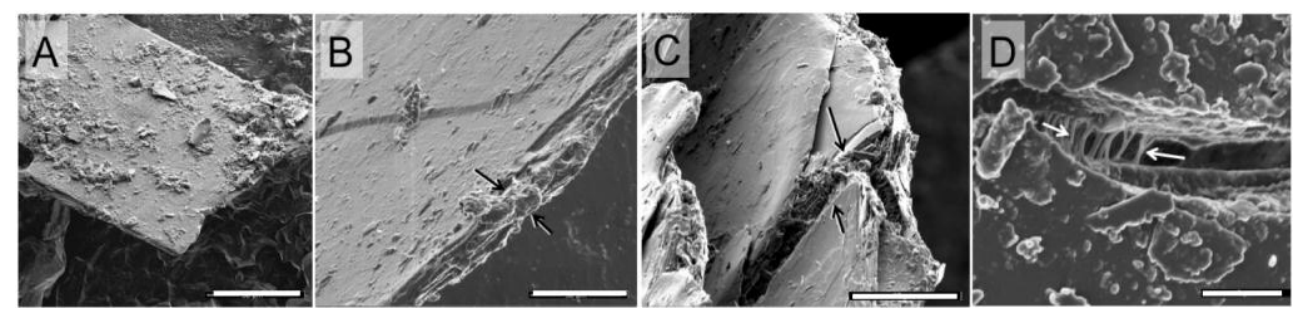

Figure 8. HeIM images of organic matter residues. (A) Biotite with microbial OM surface coverage, (B) microbial EPS enrobing a biotite edge (arrows), (C,D) Intercalation of microbial OM filling mineral pores and crevices. Arrows in D point to EPS strands. Scale bars: (A) $50 \mu \mathrm{m},($ B) $20 \mu \mathrm{m},($ C) $10 \mu \mathrm{m}$, (D) $1 \mu \mathrm{m}$.

After extractions with $\mathrm{H}_{2} \mathrm{O}$ and methanol, mineral surfaces showed a residual OM signature when compared with the initial clean minerals (Figure 9). In addition, we also observed preferential microbial coverage on biotite edges and in mineral cracks and crevices. 

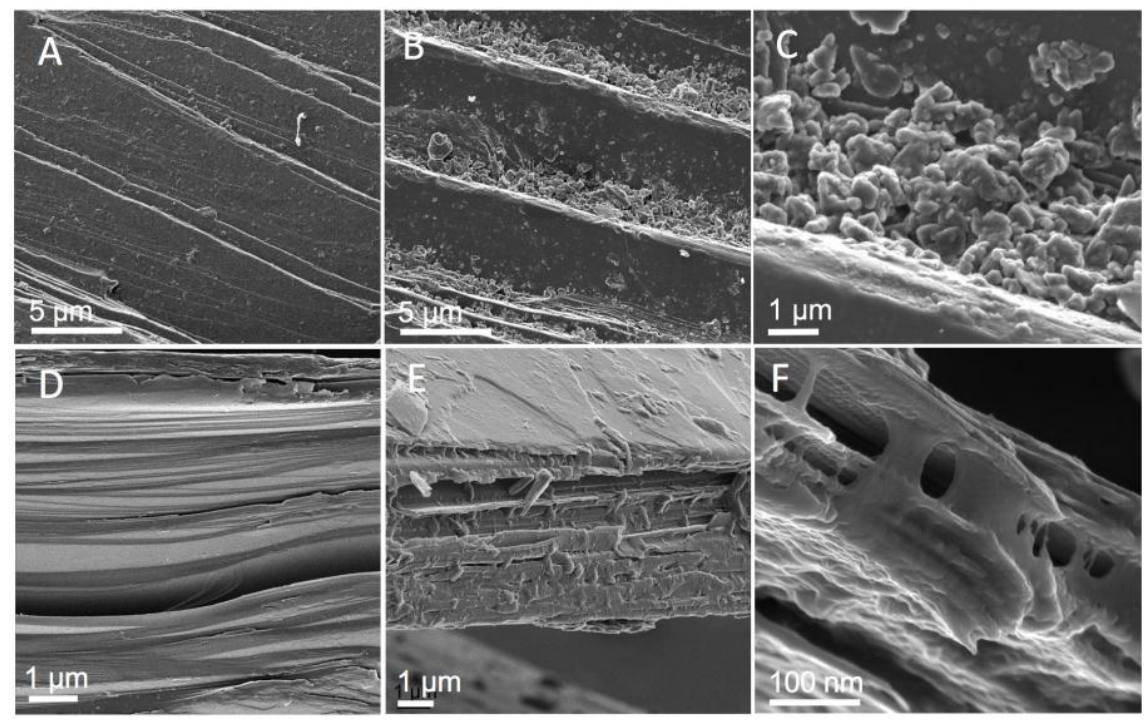

Figure 9. HeIM images of mineral surfaces after extraction with water and methanol showing a significant quantity of organic matter residue, as compared to the initial clean minerals. Original clean anorthite (A); anorthite after methanol sonicated washes (B,C). Original biotite material (D); biotite after water and methanol extraction, resp. (E,F).

\subsection{XRD and Micro-XRD}

After 9 months, minerals did not show any significant sign of crystalline change, nor any secondary mineral formation (Figures 10 and 11). However, minerals increased the relative amorphous fraction. This phenomenon was particularly evident in biotite, with pronounced intercalation of the phyllosilicate layers as also revealed by HeIM (Figure 9). The level of amorphous material detected by micro-XRD decreased in the material after the water and methanol extraction.

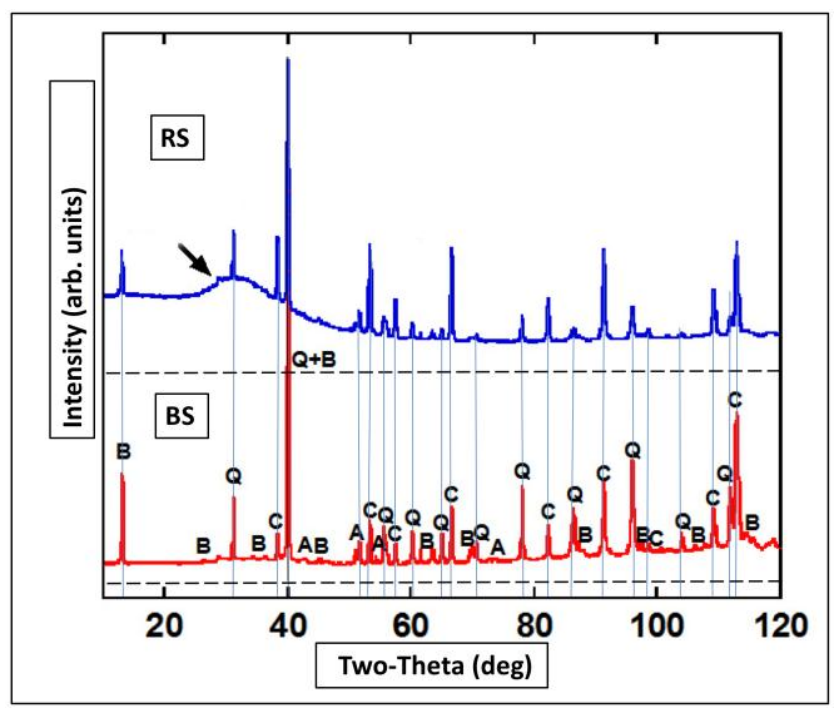

Figure 10. Micro-XRD patterns of the bulk substrate (BS) and rhizosphere soil (RS). The broadened "shoulder" peak (arrow), as well as lower intensity of signature peaks of biotite (B), quartz (Q), anorthite (A), and corundum (C) is characteristic for increased amorphous content. 


\begin{tabular}{|c|l|l|}
\hline Sample & Solvent & Weight \% \\
\hline Control & -- & $\leq 1$ \\
\hline \multirow{4}{*}{ Rhizosphere } & $\mathrm{NE}$ & $36.1 \pm 1.0$ \\
\cline { 2 - 3 } & $\mathrm{H}_{2} \mathrm{O}$ & $22.6 \pm 1.0$ \\
\cline { 2 - 3 } & $\mathrm{MeOH}$ & $24.3 \pm 1.0$ \\
\hline \multirow{3}{*}{ Bulk substrate } & $\mathrm{NE}$ & $30.7 \pm 1.0$ \\
\cline { 2 - 3 } & $\mathrm{H}_{2} \mathrm{O}$ & $14.6 \pm 1.0$ \\
\cline { 2 - 3 } & $\mathrm{MeOH}$ & $12.9 \pm 1.0$ \\
\hline
\end{tabular}

Figure 11. Results of micro-XRD quantitative analysis of the amorphous material in the rhizosphere and bulk substrate from the columns. Material was extracted with water $\left(\mathrm{H}_{2} \mathrm{O}\right)$, methanol $(\mathrm{MeOH})$, and non-extracted (NE). The initial starting sonicated substrate was used as a control. Even after the extractions, amorphous material remained associated with the minerals. The error bars are within 1.0\%.

\section{Discussion}

This study evaluated how SOM is formed, stored, and protected in a laboratory experiment using red pine seedlings grown in a designed mineral matrix with forest soil microbial inoculum. Our main findings were: (a) soil microorganisms in the initially OM-free column experiment were able to transform and stabilize red pine root exudates into a variety of $C$ compounds with varying projected residence times, (b) a significant amount of plant- and microbially-derived biomass was contributed to the mineral matrix, and (c) residual microbial biomass stayed in the system even after extraction of soil minerals with different solvents. All of the main findings support our hypothesis that plant and microbial OM significantly contributes to the pool of stabilized $\mathrm{C}$ in soils.

\subsection{Rhizospheric Microbiome}

Despite the growing interest in characterizing the microbiome from the soil rhizosphere, there is less known about microbial communities adapted to survive solely on root exudates [46]. In this nutrient-limited environment, the microbial community was preferentially located within the rhizosphere. The core community members in this ecological niche had to obtain energy from root exudates as their primary $\mathrm{C}$ source, and additionally, to access and mobilize cations $(\mathrm{K}, \mathrm{Ca})$ by mineral weathering. Our system contained a high percentage of Burkholderiales, Gram-negative proteobacteria, that are typically present in intimate association with fresh organic matter [47]. Conversely, Actinomycetes, a group of Gram positive bacteria also present in our system, are adapted to nutrient poor environments [48]. The greater abundance of Pseudomonadales and Acidobacter is attributed to these families being ubiquitous in soils. Also, nitrogen-fixing, plant root symbiotic Rhizobiales were present in our samples. Many genera within the relatively abundant Bradyrhizobiaceae are recognized for their nitrogen cycling capabilities, such as biological nitrogen fixation in the genus Bradyrhizobium or nitrogen mineralization from species in the genus Nitrobacter [49]. Bradyrhizobium is also known to form symbiotic relationships with plants, mainly legumes, but have not been reported to form symbiotic relationships with pines. The majority of OTUs associated with Bradyrhizobiaceae observed in our samples had no assigned genus, and of the ones that did, Bradyrhizobium was the most abundant. Common carbon sources for microorganisms from the Bradyrhizobium genus include carbohydrates and organic acids, with nitrates being also a common nitrogen source [49]. This suggests that in our samples Bradyrhizobium and other bacteria from the Rhizobiales were most likely in a free-living state and survived on organic acids from root exudates because there were very little carbohydrate-like compounds identified via FTICR in the rhizospheric soil.

The second most common family-level OTUs observed from Rhizobiales was Hyphomicrobiaceae, mainly from the genera Devosia, Hyphomicrobium, and Rhodoplanes. This diverse family is known 
for having oligocarbophilic organisms, i.e., organisms adapted to low carbon environments [50,51], which is consistent with the soil environment provided in this study. While many of Hyphomicrobiaceae genera are aerobic chemoheterotrophs (e.g., Devosia spp.) or chemoorganotrophs (e.g., Hyphomicrobium spp.); there are some that are facultative anaerobes that respire nitrate (e.g., Rhodoplanes spp.) [51,52]. Hyphomicrobium spp. are widely distributed in soils, produce hyphae, and are especially adapted to growing in low resource conditions [51]. Hyphomicrobium spp. can even thrive on methanol [51]. Overall, Hyphomicrobium spp. has been observed growing autotrophically using $\mathrm{CO}_{2}, \mathrm{H}_{2}$, and $\mathrm{O}_{2}$ [53]. As such, it is not surprising that we observed microorganisms that thrive on low $\mathrm{C}$ sources and in both anaerobic and aerobic environments in soils that received no exogenous $C$ substrates or other resources (with the exception of the root exudates) throughout the duration of our experiment.

We also observed a small abundance of Methylobacterium spp., a group of facultative methylotrophic bacteria, suggesting that methanol was present in the rhizosphere, possibly from the $P$. resinosa roots themselves [54]. Methylobacterium have also been shown to form symbiotic relationships with plants and to promote plant growth via urease production or enzymes that promote disease resistance and have been used with other plant growth-promoting bacteria as inoculants in agricultural cropping systems [55]. Thus, it appears that the microbial community located in the rhizosphere used various forms of $C$ and a variety of electron acceptors. These findings were consistent with our FTIC-MS data that revealed a wide diversity of carbon compounds in the rhizosphere samples compared to the bulk soil.

Although pine naturally exist in a relationship with ectomycorrhizal and saprotrophic fungi which significantly contribute to C cycling by SOM decomposition [56,57], here we focused only on bacteria from the perspective of microbial ecology, to obtain information on the structure and function of the microbial community members that were able to sustain in these humics-free basic conditions.

\subsection{Molecular Characterization of Rhizospheric Biomass}

Molecular characterization of $\mathrm{C}$ compounds has become a necessity in studies focused on SOM stabilization mechanisms. Conventional thermal destructive procedures [58], and wet oxidative treatment methods for isolation of SOM in soils, including hydrogen peroxide $\left(\mathrm{H}_{2} \mathrm{O}_{2}\right)$ [59], potassium permanganate $\left(\mathrm{KMnO}_{4}\right)$ [60], disodium peroxodisulphate $\left(\mathrm{Na}_{2} \mathrm{~S}_{2} \mathrm{O}_{8}\right)$ [61], or sodium hypochlorite $\mathrm{NaOCl}[19,62]$, all result in some alteration of mineral soil constituents. Thus, we used a SOM extraction method employing solvents with distinct polarities. Although the result was not a complete extraction of the SOM material adhered to the mineral surfaces, the portion of the extracted material was representative of the overall labile SOM [34]. By this method, we were able to identify a wide variety of bio(macro)molecular signatures, ranging from low molecular weight root exudates (such as small protein-fragments and amino sugars) to high molecular weight substances (such as lignin-like and aromatic compounds). These bio(macro)molecular compounds were not present at the start of the experiment and were only produced in situ. These compounds have varying turnover times, ranging from labile to intermediate and refractory SOM pool components (Figure 1). These results were consistent with our microbial data that revealed greater abundance of microbial communities in the rhizosphere samples compared to the bulk material, where it was difficult to find and amplify a microbial DNA signal. Given that our sterilized soil initially did not contain any SOM material, we believe the majority of these compounds were produced by microbial activity. Additional evidence of this is the presence of a pool of refractory OM that was observed in the rhizospheric sample and was thus assumed to have originated from the microbial communities (i.e., lipid-like and aromatic compounds) (Figure 1). However, in the overall $C$ budget, we must also consider another $C$ source. Plant material produced by rhizodeposition, such as root mucilage, sloughed-off epidermal roots cells, and root hair and cortical dead root cells [63] also provide a variety of low molecular weight solutes [64] readily processed and respired by microorganisms as $\mathrm{CO}_{2}$.

The small amount of recalcitrant lipid-like and aromatic compounds in the bulk soil indicated a small signature of necromass that was transported away from the root by bulk flow into the 
surrounding area. Additionally, microorganisms in this nutrient-limited system needed to be located within the rhizosphere for survival, which explains the lack of microbial signal and the lack of SOM diversity in bulk soil samples.

The FTICR results indicated that a large variety of newly-formed organic $C$ compounds were formed in this system, with their chemical attributes giving a perspective to the projected turnover time of the newly formed SOM (Figure 1). These data suggest that rhizosphere supported a relatively active and diverse ecosystem enriched with a wide range of organic labile and recalcitrant molecules compared to the bulk substrate samples that were mainly enriched with aromatic and lipid-like compounds, a part of the refractory SOM pool. However, given that SOM stabilization and decomposition is a multifaceted dynamic process, this can only provide fundamental information on SOM turnover modeling to help understanding the transport and fate of the SOM.

\subsection{Correlated Imaging of Extracted Material}

As previously mentioned, two solvents were used to extract a wide range of organic molecules from the soil because no single solvent would be able to extract SOM compounds that are known to have different polarities and different chemistries. The process of FTICR analyses using differences in SOM composition between water- and methanol-extracted organic compounds initiated the idea of their correlated visualization by electron microscopy, since to our knowledge, SOM has not been imaged by high resolution electron microscopy before. Comparative TEM imaging of soil organic matter extracted with water and methanol validated our perception of hydrophilic and hydrophobic SOM components, by showing their clear morphological differences (Figure 8). The water-extracted material was indicative of water-soluble low molecular weight organic substances, likely forming colloids suspended in water, consistent with the operational definition of dissolved organic matter (DOM) adopted: "the organic carbon smaller than $0.45 \mu \mathrm{m}$ in diameter" [65]. As revealed by FTICR, the major class of water-soluble dissolved organic carbon compounds contained carboxylic, hydroxyl, and phenolic functional groups. In contrast, the SOM material extracted with methanol contained micro- and nano- spherical structures resembling a lipid emulsion that corresponds with the concept of colloidal OM that contained components larger in molecular weight, and contain fewer carboxylic and hydroxyl functional groups than the water-soluble phase. The functional hydrophilic $(\mathrm{C}=\mathrm{O})$ and hydrophobic $(\mathrm{C}-\mathrm{H})$ groups of the SOM formed in the rhizosphere determine the wettable (hydrophilic) and water-repellent (hydrophobic) soil features, as they directly influence properties such as soil wettability, water repellency, and microaggregation [66]. This in turn influences soil moisture retention, soil fertility, and water movement in soils.

We presume the presence of stabilized yet mobile particulate organic $C$ compounds released in the aqueous phase had originated from microbial decomposition. This process is carried out by the oxidative depolymerization of organic $\mathrm{C}$ molecules, and it occurs due to the incorporation of oxygen-containing functional groups to SOM [67]. This reduces the $\mathrm{C}$ compounds molecular size and ultimately improves water solubility.

Overall, the immense importance of carboxyl groups for both the aqueous solubility and the chemical reactivity of $\mathrm{OM}$ in soils has been well recognized. These chemical and physical properties have implications on chemical reactivity, stability, interaction with mineral surfaces, and OM mobility in soils, all of which ultimately define how persistent SOM is in soils $[8,17]$.

\subsection{SOM Association with Mineral Surfaces}

Another microscopy imaging technique, Helium ion microscopy, revealed possible mechanisms of SOM stabilization in this system. The majority of organic compounds were intimately associated with mineral phases, as anticipated based on standard texts $[68,69]$, and our previous observation of a similar system [32]. For instance, frequently seen occlusion and intercalation may cause spatial inaccessibility against abiotic and microbial decomposition (Figure 8). Krull at al. 2003 [70] reviewed mechanisms and processes of SOM stabilization, and concluded that adsorption on mineral surfaces 
and particles aggregation can impede decomposition processes but 'molecular recalcitrance' appears to be the main mechanism by which soil OM can be stabilized for longer periods of time. Subsequently, Von Lützov et al. in their review [29] established that "The chemical structure of organic molecules by itself is not sufficient to account for the extreme variation of soil OM in terms of age and turnover times". Recently, Lehmann and Kleber proposed the soil continuum model that reclassifies the concept of soil mineral protection of organic matter from microbial decomposition [17]. They recognized the SOM spatial architecture within the minerals matrix as a key factor how the SOM is protected from microbial access, rather than merely for its 'stable' chemical nature. Thus, the role of spatial inaccessibility is yet to be further discussed.

Given the absence of the initial OM substances in the designed mineral matrix, we attribute all observed and analyzed $C$ compounds to de novo synthesis by rhizodeposition and microbial activity. As such, the robust presence of organic material associated with the mineral substrates even after the solvent treatments (Figure 9) suggests the stabilization of the organic matter adhered on the mineral edges and surfaces and intercalated into the phyllosilicate layers. We observed that mineral surfaces were used as templates for microbial attachment with EPS which suggests that the rhizospheric microorganisms acquired metal cations necessary for metabolic processes via microbial specific adhesion mechanisms [67]. The subsequent biofilm formation supports creating the micro-habitat to access mineral-associated organic substrates, for nutrient uptake and mobilizing metal cations from minerals by microbial electron transfer [71,72].

Overall, our results confirmed the incorporation of the organic material into mineral matrix that resulted in formation of stabilized amorphous phase. Based on our multimodal analytical approach, this supports our projection that microbial biomass will be significantly contributing to the refractory $\mathrm{C}$ pool in soils. Further work needs be done to quantify the production and incorporation of organic material into the mineral matrix into soil organic $C$ microbial models [73-75].

\subsection{XRD of Minerals with Amorphous SOM}

Different soil minerals possess different capacities to adsorb and protect organic matter as a result of mineral-specific properties such as surface area, charge characteristics, and porosity [70]. Soil mineral matrices such as clays and poorly crystalline minerals [76] can influence $C$ retention, stability and turnover due to their ability to physically protect organic $C$ against decomposition. Our results confirmed this, as we were able to correlate the SEM images of minerals, especially biotite, with substantial organic $C$ deposits, and with $\mathrm{X}$-ray diffraction patterns characteristic for inclusion of amorphous matter. Although the X-ray diffraction and micro-XRD did not provide clear evidence of the initial minerals' crystallinity alteration or secondary mineral formation due to the mineral-organic associations (MOAs), this could be because of the qualitative and quantitative limitations of these methods. Thus, we do not discount the possibility of the initial stages of mineral weathering that were just not detectable at this time point. However, we noticed higher intensity narrower peaks in bulk soil, as compared to reduced intensity and a higher background "shoulder" in rhizosphere (Figure 10, arrows). These low-intensity, broad peaks are indicative of X-rays scattering distributed in a wide range (2 Theta), characteristic of an amorphous impurity, attributed to an increased amorphous content in the RS sample. This partial amorphization was caused by biogenic organic compounds associated with the mineral surfaces and incorporated within the mineral edges. The increased percentage of the amorphous material indicating the incorporation of the material produced by rhizospheric activity on and within the minerals (the above-mentioned intercalation) remained even in the material that was washed in water and methanol, indicating refractory signatures of newly formed biogenic material firmly attached to the mineral substrates (Figure 11).

Additionally, after the treatment with solvents that removed different amounts of organic matter, as evidenced by SEM imaging, the XRD patterns still showed pronounced signs of incorporation of amorphous material into their crystalline mineral content, indicating a certain degree of protection exerted by the mineral matrix. We assume the solvents removed the labile organic $C$ from the samples, 
with the majority of intermediate and refractory OM remaining attached to the mineral surfaces. With water as the most common solvent present in natural systems, we assume the concentration of hydrophobic compounds on mineral surface would increase in time.

\section{Conclusions}

Our study showed that soil microorganisms in the initially OM-free column experiment were able to transform red pine root exudates into a variety of $C$ compounds with various degrees of inherent recalcitrance, and a substantial amount of biomass became incorporated in the system. We also saw evidence that residual microbial biomass persisted in the system even after extractions with different solvents, which suggested that microbial necromass may contribute to the intermediate and refractory SOM pool in soils. Our short-term results support the idea that SOM binding to soil minerals [77] is a major pathway for organic carbon sequestration in soil. This study contributed to advancing our understanding of the formation and fate of root carbon, and the persistence of SOM requires disentangling the complex interactions between root exudates and debris, microbial communities, and soil minerals.

Acknowledgments: This research was performed at the Environmental Molecular Sciences Laboratory (EMSL), a national scientific user facility sponsored by the Department of Energy's Office of Biological and Environmental Research, located at the Pacific Northwest National Laboratory. PNNL is operated for DOE by Battelle Memorial Institute under Contract\# DE-AC05-76RL0-1830. Financial support was provided by EMSL's Seed Laboratory Directed Research and Development (LDRD) program and NSF grant EAR 09-52399. The column experiment was carried out in growth-chamber facilities operated by the WSU School of Biological Sciences under the able supervision of Charles Cody. We gratefully acknowledge Sarah Owens' group at the Biosciences Division's Environmental Sample Preparation and Sequencing Core at Argonne National Laboratory for the sequencing work. The authors thank Zsuzsanna Balogh-Brunstad for helpful comments, and Daryl Stacks for assistance with the experiment. We thank three anonymous reviewers and the editor for their insightful comments that greatly improved the manuscript.

Author Contributions: C.K.K. designed the experiment and co-wrote the paper; A.C.D. designed the analytical approach, performed the EM imaging and wrote the paper; A.P.S. provided data analyses and co-wrote the paper, M.M.T. and R.K.C. performed the FTICR experiment, data analysis and co-wrote the paper; A.R.C. acquired material for 16S rRNA sequencing; C.J.B. performed bioinformatics analyses; T.V. performed X.R.D. and analyzed data; Z.S. contributed to the experimental setup and co-wrote the paper; L.S.T. and J.B.H. co-wrote the paper.

Conflicts of Interest: The authors declare no conflict of interest.

\section{References}

1. Houghton, R.A. Balancing the global carbon budget. Annu Rev. Earth Planet. Sci. 2007, 35, 313-347. [CrossRef]

2. Köchy, M.; Hiederer, R.; Freibauer, A. Global distribution of soil organic carbon-Part 1: Masses and frequency distributions of SOC stocks for the tropics, permafrost regions, wetlands, and the world. SOIL 2015, 1, 351-365. [CrossRef]

3. Jiao, N.; Herndl, G.J.; Hansell, D.A.; Benner, R.; Kattner, G.; Wilhelm, S.W.; Kirchman, D.L.; Weinbauer, M.G.; Luo, T.W.; Chen, F.; et al. Microbial production of recalcitrant dissolved organic matter: Long-term carbon storage in the global ocean. Nat. Rev. Microbiol. 2010, 8, 593-599. [CrossRef] [PubMed]

4. Liang, C.; Balser, T.C. Microbial production of recalcitrant organic matter in global soils: Implications for productivity and climate policy. Nat. Rev. Microbiol. 2011, 9. [CrossRef] [PubMed]

5. Benner, R. Biosequestration of carbon by heterotrophic microorganisms. Nat. Rev. Microbiol. 2011, 9. [CrossRef] [PubMed]

6. Kleber, M.; Johnson, M.G. Advances in Understanding the Molecular Structure of Soil Organic Matter: Implications for Interactions in the Environment. Adv. Agron. 2010, 106, 77-142. [CrossRef]

7. Marschner, B.; Brodowski, S.; Dreves, A.; Gleixner, G.; Gude, A.; Grootes, P.M.; Hamer, U.; Heim, A.; Jandl, G.; Ji, R.; et al. How relevant is recalcitrance for the stabilization of organic matter in soils? J. Plant Nutr. Soil Sci. 2008, 171, 91-110. [CrossRef]

8. Schmidt, M.W.I.; Torn, M.S.; Abiven, S.; Dittmar, T.; Guggenberger, G.; Janssens, I.A.; Kleber, M.; Kogel-Knabner, I.; Lehmann, J.; Manning, D.A.C.; et al. Persistence of soil organic matter as an ecosystem property. Nature 2011, 478, 49-56. [CrossRef] 
9. Cotrufo, M.F.; Wallenstein, M.D.; Boot, C.M.; Denef, K.; Paul, E. The Microbial Efficiency-Matrix Stabilization (MEMS) framework integrates plant litter decomposition with soil organic matter stabilization: Do labile plant inputs form stable soil organic matter? Glob. Chang. Biol. 2013, 19, 988-995. [CrossRef] [PubMed]

10. Castellano, M.J.; Mueller, K.E.; Olk, D.C.; Sawyer, J.E.; Six, J. Integrating plant litter quality, soil organic matter stabilization, and the carbon saturation concept. Glob. Chang. Biol. 2015, 21, 3200-3209. [CrossRef] [PubMed]

11. Anderson, T.H.; Joergensen, R.G. Relationship between SIR and FE estimates of microbial biomass C in deciduous forest soils at different pH. Soil Biol. Biochem. 1997, 29, 1033-1042. [CrossRef]

12. Kindler, R.; Miltner, A.; Richnow, H.H.; Kastner, M. Fate of gram-negative bacterial biomass in soilMineralization and contribution to SOM. Soil Biol. Biochem. 2006, 38, 2860-2870. [CrossRef]

13. Kindler, R.; Miltner, A.; Thullner, M.; Richnow, H.H.; Kastner, M. Fate of bacterial biomass derived fatty acids in soil and their contribution to soil organic matter. Org. Geochem. 2009, 40, 29-37. [CrossRef]

14. Potthoff, M.; Dyckmans, J.; Flessa, H.; Beese, F.; Joergensen, R.G. Decomposition of maize residues after manipulation of colonization and its contribution to the soil microbial biomass. Biol. Fertil. Soils 2008, 44, 891-895. [CrossRef]

15. Simpson, A.J.; Simpson, M.J.; Smith, E.; Kelleher, B.P. Microbially derived inputs to soil organic matter: Are current estimates too low? Environ. Sci. Technol. 2007, 41, 8070-8076. [CrossRef] [PubMed]

16. Schimel, J. Soil Carbon Microbes and Global Carbon. Nat. Clim. Chang. 2013, 3, 867-868. [CrossRef]

17. Lehmann, J.; Kleber, M. The contentious nature of soil organic matter. Nature 2015, 528, 60-68. [CrossRef] [PubMed]

18. Oburger, E.; Schmidt, H. New Methods To Unravel Rhizosphere Processes. Trends Plant Sci. 2016, 21, $243-255$. [CrossRef] [PubMed]

19. Mikutta, R.; Kleber, M.; Torn, M.S.; Jahn, R. Stabilization of soil organic matter: Association with minerals or chemical recalcitrance? Biogeochemistry 2006, 77, 25-56. [CrossRef]

20. Pett-Ridge, J.; Firestone, M.K. Using stable isotopes to explore root-microbe-mineral interactions in soil. Rhizosphere 2017, 3, 244-253. [CrossRef]

21. Kuzyakov, Y.; Blagodatskaya, E. Microbial hotspots and hot moments in soil: Concept \& review. Soil Biol. Biochem. 2015, 83, 184-199. [CrossRef]

22. Marschner, H. Marschner's Mineral Nutrition of Higher Plants, 3rd ed.; Academic Press: Cambridge, MA, USA, 2012.

23. Kuzyakov, Y.; Domanski, G. Carbon input by plants into the soil. Review. J. Plant Nutr Soil Sci. 2000, 163, 421-431. [CrossRef]

24. Rasse, D.P.; Rumpel, C.; Dignac, M.F. Is soil carbon mostly root carbon? Mechanisms for a specific stabilisation. Plant Soil 2005, 269, 341-356. [CrossRef]

25. Yang, C.H.; Crowley, D.E. Rhizosphere microbial community structure in relation to root location and plant iron nutritional status. Appl. Environ. Microbiol. 2000, 66, 345-351. [CrossRef] [PubMed]

26. Keiluweit, M.; Bougoure, J.J.; Nico, P.S.; Pett-Ridge, J.; Weber, P.K.; Kleber, M. Mineral protection of soil carbon counteracted by root exudates. Nat. Clim. Chang. 2015, 5, 588-595. [CrossRef]

27. Balogh-Brunstad, Z.; Keller, C.K.; Bormann, B.T.; O’Brien, R.; Wang, D.; Hawley, G. Chemical weathering and chemical denudation dynamics through ecosystem development and disturbance. Glob. Biogeochem. Cycles 2008, 22. [CrossRef]

28. Lorenz, K.; Lal, R.; Preston, C.M.; Nierop, K.G.J. Strengthening the soil organic carbon pool by increasing contributions from recalcitrant aliphatic bio(macro)molecules. Geoderma 2007, 142, 1-10. [CrossRef]

29. von Lutzow, M.; Kogel-Knabner, I.; Ekschmitt, K.; Matzner, E.; Guggenberger, G.; Marschner, B.; Flessa, H. Stabilization of organic matter in temperate soils: Mechanisms and their relevance under different soil conditions-A review. Eur. J. Soil Sci. 2006, 57, 426-445. [CrossRef]

30. Balogh-Brunstad, Z.; Keller, C.K.; Gill, R.A.; Bormann, B.T.; Li, C.Y. The effect of bacteria and fungi on chemical weathering and chemical denudation fluxes in pine growth experiments. Biogeochemistry 2008, 88, 153-167. [CrossRef]

31. Koide, R.T.; Kabir, Z. Nutrient economy of red pine is affected by interactions between Pisolithus tinctorius and other forest-floor microbes. New Phytol. 2001, 150, 179-188. [CrossRef] 
32. Shi, Z.Q.; Balogh-Brunstad, Z.; Grant, M.; Harsh, J.; Gill, R.; Thomashow, L.; Dohnalkova, A.; Stacks, D.; Letourneau, M.; Keller, C.K. Cation uptake and allocation by red pine seedlings under cation-nutrient stress in a column growth experiment. Plant Soil 2014, 378, 83-98. [CrossRef]

33. Bormann, B.T.; Wang, D.; Bormann, F.H.; Benoit, G.; April, R.; Snyder, M.C. Rapid, plant-induced weathering in an aggrading experimental ecosystem. Biogeochemistry 1998, 43, 129-155. [CrossRef]

34. Tfaily, M.M.; Chu, R.K.; Tolic, N.; Roscioli, K.M.; Anderton, C.R.; Pasa-Tolic, L.; Robinson, E.W.; Hess, N.J. Advanced Solvent Based Methods for Molecular Characterization of Soil Organic Matter by High-Resolution Mass Spectrometry. Anal. Chem. 2015, 87, 5206-5215. [CrossRef]

35. Caporaso, J.G.; Lauber, C.L.; Walters, W.A.; Berg-Lyons, D.; Huntley, J.; Fierer, N.; Owens, S.M.; Betley, J.; Fraser, L.; Bauer, M. Ultra-high-throughput microbial community analysis on the Illumina HiSeq and MiSeq platforms. ISME J. 2012, 6, 1621-1624. [CrossRef] [PubMed]

36. Aronesty, E. EA-Utils: Command-Line Tools for Processing Biological Sequencing Data. Available online: https:/ / expressionanalysis.github.io/ea-utils/ (accessed on 22 February 2017).

37. Caporaso, J.G.; Kuczynski, J.; Stombaugh, J.; Bittinger, K.; Bushman, F.D.; Costello, E.K.; Fierer, N.; Pena, A.G.; Goodrich, J.K.; Gordon, J.I.; et al. QIIME allows analysis of high-throughput community sequencing data. Nat. Methods 2010, 7, 335-336. [CrossRef] [PubMed]

38. Rognes, T.; Flouri, T.; Nichols, B.; Quince, C.; Mahe, F. VSEARCH: A versatile open source tool for metagenomics. PeerJ 2016, 4, e2584. [CrossRef] [PubMed]

39. Edgar, R.C.; Haas, B.J.; Clemente, J.C.; Quince, C.; Knight, R. UCHIME improves sensitivity and speed of chimera detection. Bioinformatics 2011, 27, 2194-2200. [CrossRef] [PubMed]

40. McDonald, D.; Price, M.N.; Goodrich, J.; Nawrocki, E.P.; DeSantis, T.Z.; Probst, A.; Andersen, G.L.; Knight, R.; Hugenholtz, P. An improved Greengenes taxonomy with explicit ranks for ecological and evolutionary analyses of bacteria and archaea. ISME J. 2012, 6, 610-618. [CrossRef] [PubMed]

41. Price, M.N.; Dehal, P.S.; Arkin, A.P. FastTree: Computing Large Minimum Evolution Trees with Profiles instead of a Distance Matrix. Mol. Biol. Evol. 2009, 26, 1641-1650. [CrossRef] [PubMed]

42. Kujawinski, E.B.; Behn, M.D. Automated analysis of electrospray ionization Fourier transform ion cyclotron resonance mass spectra of natural organic matter. Anal. Chem. 2006, 78, 4363-4373. [CrossRef] [PubMed]

43. Kujawinski, E.B.; Longnecker, K.; Blough, N.V.; Del Vecchio, R.; Finlay, L.; Kitner, J.B.; Giovannoni, S.J. Identification of possible source markers in marine dissolved organic matter using ultrahigh resolution mass spectrometry. Geochim. Cosmochim. Acta 2009, 73, 4384-4399. [CrossRef]

44. Kim, S.; Kramer, R.W.; Hatcher, P.G. Graphical method for analysis of ultrahigh-resolution broadband mass spectra of natural organic matter, the van Krevelen diagram. Anal. Chem. 2003, 75, 5336-5344. [CrossRef] [PubMed]

45. Madsen, I.C.; Scarlett, N.V.Y. Quantitative Phase Analysis. In Powder Diffraction: Theory and Practice; Dinnabier, R.E., Ed.; Royal Society of Chemistry: London, UK, 2008.

46. Mendes, R.; Garbeva, P.; Raaijmakers, J.M. The rhizosphere microbiome: Significance of plant beneficial, plant pathogenic, and human pathogenic microorganisms. Fems Microbiol. Rev. 2013, 37, 634-663. [CrossRef] [PubMed]

47. Bastian, F.; Bouziri, L.; Nicolardot, B.; Ranjard, L. Impact of wheat straw decomposition on successional patterns of soil microbial community structure. Soil Biol. Biochem. 2009, 41, 262-275. [CrossRef]

48. Eskelinen, A.; Stark, S.; Mannisto, M. Links between plant community composition, soil organic matter quality and microbial communities in contrasting tundra habitats. Oecologia 2009, 161, 113-123. [CrossRef]

49. De Souza, J.A.M.; Alves, L.M.C.; de Mello Varani, A.; de Macedo Lemos, E.G. The Family Bradyrhizobiaceae. In The Prokaryotes; Springer: Berlin/Heidelberg, Germany, 2014; pp. 135-154.

50. Gliesche, E.A. Genus Hyphomicrobium Stutzer and Hartleb 1898, 76AL. In Bergey's Manual of Systematic Bacteriology; Williams and Wilkins: Baltimore, MD, USA, 2005; pp. 476-494.

51. Oren, E.A. The family Hyphomicrobiaceae. In The Prokaryotes; Springer: Berlin/Heidelberg, Germany, 2014; pp. 247-281.

52. Okamura, K.; Kanbe, T.; Hiraishi, A. Rhodoplanes serenus sp nov, a purple non-sulfur bacterium isolated from pond water. Int. J. Syst Evol. Microbiol. 2009, 59, 531-535. [CrossRef]

53. Uebayasi, M.; Tomizuka, N.; Kamibayashi, A.; Tonomura, K. Autotrophic Growth of a Hyphomicrobium Sp and Its Hydrogenase Activity. Agric. Biol. Chem. 1981, 45, 1783-1790. [CrossRef] 
54. Sy, A.; Timmers, A.C.J.; Knief, C.; Vorholt, J.A. Methylotrophic metabolism is advantageous for Methylobacterium extorquens during colonization of Medicago truncatula under competitive conditions. Appl. Environ. Microbiol. 2005, 71, 7245-7252. [CrossRef]

55. Madhaiyan, M.; Poonguzhali, S.; Kang, B.G.; Lee, Y.J.; Chung, J.B.; Sa, T.M. Effect of co-inoculation of methylotrophic Methylobacterium oryzae with Azospirillum brasilense and Burkholderia pyrrocinia on the growth and nutrient uptake of tomato, red pepper and rice. Plant Soil 2010, 328, 71-82. [CrossRef]

56. Phillips, L.A.; Ward, V.; Jones, M.D. Ectomycorrhizal fungi contribute to soil organic matter cycling in sub-boreal forests. ISME J. 2014, 8, 699-713. [CrossRef] [PubMed]

57. Shah, F.; Nicolas, C.; Bentzer, J.; Ellstrom, M.; Smits, M.; Rineau, F.; Canback, B.; Floudas, D.; Carleer, R.; Lackner, G.; et al. Ectomycorrhizal fungi decompose soil organic matter using oxidative mechanisms adapted from saprotrophic ancestors. New Phytol. 2016, 209, 1705-1719. [CrossRef] [PubMed]

58. Mayer, L.M.; Xing, B.S. Organic matter-surface area relationships in acid soils. Soil Sci. Soc. Am. J. 2001, 65, 250-258. [CrossRef]

59. Leifeld, J.; Kogel-Knabner, I. Organic carbon and nitrogen in fine soil fractions after treatment with hydrogen peroxide. Soil Biol. Biochem. 2001, 33, 2155-2158. [CrossRef]

60. Tian, J.; Lu, S.H.; Fan, M.S.; Li, X.L.; Kuzyakov, Y. Labile soil organic matter fractions as influenced by non-flooded mulching cultivation and cropping season in rice-wheat rotation. Eur. J. Soil Biol. 2013, 56, 19-25. [CrossRef]

61. Eusterhues, K.; Rumpel, C.; Kleber, M.; Kogel-Knabner, I. Stabilisation of soil organic matter by interactions with minerals as revealed by mineral dissolution and oxidative degradation. Org. Geochem. 2003, 34, 1591-1600. [CrossRef]

62. Siregar, A.; Kleber, M.; Mikutta, R.; Jahn, R. Sodium hypochlorite oxidation reduces soil organic matter concentrations without affecting inorganic soil constituents. Eur. J. Soil Sci. 2005, 56, 481-490. [CrossRef]

63. Jones, D.L.; Hodge, A.; Kuzyakov, Y. Plant and mycorrhizal regulation of rhizodeposition. New Phytol. 2004, 163, 459-480. [CrossRef]

64. Farrar, J.; Hawes, M.; Jones, D.; Lindow, S. How roots control the flux of carbon to the rhizosphere. Ecology 2003, 84, 827-837. [CrossRef]

65. Thurman, E.M. Organic Geochemistry of Natural Waters; Kluwer Academic Publishers: Hingham, MA, USA, 1985.

66. Urbanek, E.; Hallett, P.; Feeney, D.; Horn, R. Water repellency and distribution of hydrophilic and hydrophobic compounds in soil aggregates from different tillage systems. Geoderma 2007, 140, 147-155. [CrossRef]

67. Kleber, M.; Eusterhues, K.; Keiluweit, M.; Mikutta, C.; Mikutta, R.; Nico, P.S. Mineral-Organic Associations: Formation, Properties, and Relevance in Soil Environments. Adv. Agron. 2015, 130, 1-140. [CrossRef]

68. Torn, M.S.; Trumbore, S.E.; Chadwick, O.A.; Vitousek, P.M.; Hendricks, D.M. Mineral control of soil organic carbon storage and turnover. Nature 1997, 389, 170-173. [CrossRef]

69. Baisden, W.T.; Amundson, R.; Cook, A.C.; Brenner, D.L. Turnover and storage of C and N in five density fractions from California annual grassland surface soils. Glob. Biogeochem. Cycles 2002, 16, 64-1-64-19. [CrossRef]

70. Krull, E.S.; Baldock, J.A.; Skjemstad, J.O. Importance of mechanisms and processes of the stabilisation of soil organic matter for modelling carbon turnover. Funct. Plant Biol. 2003, 30, 207-222. [CrossRef]

71. Fredrickson, J.K.; Zachara, J.M. Electron transfer at the microbe-mineral interface: A grand challenge in biogeochemistry. Geobiology 2008, 6, 245-253. [CrossRef] [PubMed]

72. Reardon, C.L.; Dohnalkova, A.C.; Nachimuthu, P.; Kennedy, D.W.; Saffarini, D.A.; Arey, B.W.; Shi, L.; Wang, Z.; Moore, D.; Mclean, J.S.; et al. Role of outer-membrane cytochromes MtrC and OmcA in the biomineralization of ferrihydrite by Shewanella oneidensis MR-1. Geobiology 2010, 8, 56-68. [CrossRef] [PubMed]

73. Wieder, W.R.; Bonan, G.B.; Allison, S.D. Global soil carbon projections are improved by modelling microbial processes. Nat. Clim. Chang. 2013, 3, 909-912. [CrossRef]

74. Lawrence, C.R.; Neff, J.C.; Schimel, J.P. Does adding microbial mechanisms of decomposition improve soil organic matter models? A comparison of four models using data from a pulsed rewetting experiment. Soil Biol. Biochem. 2009, 41, 1923-1934. [CrossRef] 
75. Wieder, W.R.; Grandy, A.S.; Kallenbach, C.M.; Bonan, G.B. Integrating microbial physiology and physio-chemical principles in soils with the MIcrobial-MIneral Carbon Stabilization (MIMICS) model. Biogeosciences 2014, 11, 3899-3917. [CrossRef]

76. Kleber, M.; Mikutta, R.; Torn, M.S.; Jahn, R. Poorly crystalline mineral phases protect organic matter in acid subsoil horizons. Eur. J. Soil Sci. 2005, 56, 717-725. [CrossRef]

77. Six, J.; Conant, R.T.; Paul, E.A.; Paustian, K. Stabilization mechanisms of soil organic matter: Implications for C-saturation of soils. Plant Soil 2002, 241, 155-176. [CrossRef]

C 2017 by the authors. Licensee MDPI, Basel, Switzerland. This article is an open access article distributed under the terms and conditions of the Creative Commons Attribution (CC BY) license (http:// creativecommons.org/licenses/by/4.0/). 